\title{
Who may heal? A plea from traditional healers to participate in treating Covid-19
}

\begin{tabular}{|c|c|}
\hline \multicolumn{2}{|c|}{$\begin{array}{l}\text { Author: } \\
\text { Jaco Beyers }{ }^{1} \text { (]) }\end{array}$} \\
\hline \multicolumn{2}{|c|}{$\begin{array}{l}\text { Affiliation: } \\
\text { 'Department of Religion } \\
\text { Studies, Faculty of Theology } \\
\text { and Religion, University } \\
\text { of Pretoria, Pretoria, } \\
\text { South Africa }\end{array}$} \\
\hline \multicolumn{2}{|c|}{$\begin{array}{l}\text { Research Project Registration: } \\
\text { Project Leader: J. Beyers } \\
\text { Project Number: } 02440237\end{array}$} \\
\hline \multicolumn{2}{|c|}{$\begin{array}{l}\text { Description: This research is } \\
\text { part of the research project, } \\
\text { 'Religion, Theology and } \\
\text { Education', directed by Prof. } \\
\text { Dr Jaco Beyers, Programme } \\
\text { Manager: Biblical and } \\
\text { Religious Studies and } \\
\text { member of the Department } \\
\text { of Science of Religion and } \\
\text { Missiology, Faculty of } \\
\text { Theology and Religion, } \\
\text { University of Pretoria. }\end{array}$} \\
\hline \multicolumn{2}{|c|}{$\begin{array}{l}\text { Corresponding author: } \\
\text { Jaco Beyers, } \\
\text { jaco.beyers@up.ac.za }\end{array}$} \\
\hline \multicolumn{2}{|c|}{$\begin{array}{l}\text { Received: } 28 \text { May } 2020 \\
\text { Accepted: } 11 \text { Sept. } 2020 \\
\text { Published: } 18 \text { Nov. } 2020\end{array}$} \\
\hline \multicolumn{2}{|c|}{$\begin{array}{l}\text { How to cite this article: } \\
\text { Beyers, J., 2020, 'Who may } \\
\text { heal? A plea from traditiona } \\
\text { healers to participate in } \\
\text { treating Covid-19', HTS } \\
\text { Teologiese Studies/ } \\
\text { Theological Studies } 76(1) \text {, } \\
\text { a6169. https://doi.org/ } \\
\text { 10.4102/hts.v76i1.6169 }\end{array}$} \\
\hline \multicolumn{2}{|c|}{$\begin{array}{l}\text { Copyright: } \\
\text { (C) 2020. The Authors. } \\
\text { Licensee: AOSIS. This work } \\
\text { is licensed under the } \\
\text { Creative Commons } \\
\text { Attribution License. }\end{array}$} \\
\hline \multicolumn{2}{|l|}{ Read online: } \\
\hline 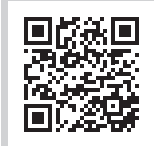 & $\begin{array}{l}\text { Scan this QR } \\
\text { code with your } \\
\text { smart phone or } \\
\text { mobile device } \\
\text { to read online. }\end{array}$ \\
\hline
\end{tabular}

Author:

Affiliation:

${ }^{1}$ Department of Religion

Studies, Faculty of Theology

and Religion, University

of Pretoria, Pretoria,

Project Leader: J. Beyers Education', directed by Prof. Dr Jaco Beyers, Programme Manager: Biblical and member of the Department of Science of Religion and

Missiology, Faculty of

Corresponding author: Jaco Beyers,

Dates: Accepted: 11 Sept. 2020

How to cite this article: Beyers, J., 2020, 'Who may healers to participate in treating Covid-19', HTS Teologiese Studies/ Theological Studies 76(1) a6169. https://doi.org/

Copyright: Licensee: AOSIS. This work is licensed under the Creative Commons Attribution License.
During 2020, communities all over the world suffered from infections and disruptions because of the Covid-19 pandemic. Health assistance in different forms was provided to assist patients. In addition, the South African Department of Health employed several measures to curb the spread of the virus. The traditional healers acting as basic health providers objected to not being asked to participate in government activities dealing with the virus. Data acquired through a qualitative approach provided insight into the pleas of traditional healers to support in the fight against Covid-19. Traditional healers were not consulted by the Department of Health, although the traditional healers are officially considered as part of the government system to provide healthcare. The Traditional Health Practitioners Act, no. 22 of 2007, provided legal recognition to traditional healers. There has been extensive written work dealing with the role of Traditional Healers in the South African healthcare system. This article investigated, through a consideration of the available literature, the differences between the Healing and Biomedical paradigms as two separate ways of presenting healthcare during the Covid-19 pandemic. Through a comparative study of the two approaches as represented by the paradigms, the reasons for not consulting and allowing traditional healers to participate in the fight against Covid-19 were investigated. Some of the reasons include the bias of science versus indigenous knowledge, as a basis for knowledge on health matters. The study recommended that traditional healers have a role to play and a contribution to make to the South African healthcare system and should be allowed to perform their activities.

Contributions: The article contributes to the understanding of how different worldviews influence the application of medical services with a particular focus on treatment provided during the Covid-19 pandemic. The contribution to treatment by traditional healers is investigated. The relation between biomedical and traditional healing is highlighted with suggestions as to future collaboration.

Keywords: traditional healers; biomedical health practitioners; Covid-19; worldview; religion; health system.

\section{Introduction}

During 2020, the world suffered from the effects of the Covid-19 virus. Different measures were employed to curb the spread of the virus. Worldwide, countries closed their borders, and households were confined to their residences. In many countries, all social interaction was prohibited as a precautionary measure to prevent the transference of the virus through physical contact. Health workers were deployed to assist in determining the extent of the spread of the virus by conducting tests, isolating the infected and providing treatment to those affected. In South Africa, similar measures were employed.

One of the organisations representing traditional healers and located in South Africa, The Traditional Healers Association of the Southern African Development Community (SADEC) ${ }^{1}$ region, responded to the South African government's measures of dealing with Covid-19 by imploring the South African government to consult and involve the traditional healers operating in rural areas to assist in fighting the spread of the virus. The chairperson of the Association, ${ }^{2}$ Dr Sylvester Hlathi, requested the Department of Health to include the traditional healers in the fight against Covid-19. Although the association did not claim to have a successful treatment or access to cure the virus, Hlathi claimed that healers could make use of traditional

\footnotetext{
1.SADEC is the Southern African Development Community and includes 16 nations in the southern region of Africa. The goal of the organization is to further social - economic and political cooperation amongst member states.
}

2.Compare a discussion later on in this article on the different bodies representing traditional healers. 
medicine to treat symptoms of the virus. The argument proposed by Hlathi states that people living in rural areas may still consult traditional healers during the time of illness because of the lack of access to health treatment provided by the Department of Health to rural areas. Traditional healers may, in some instances, be the first point of contact of people infected by the virus. Hlathi made it clear that traditional healers will heed the warning to refrain from physical contact with patients.

The plea to request traditional healers to assist in the fight against Covid-19 was reiterated by the Chairman of the Council for Traditional Healers in the Durban region, Sazi Mhlongo. According to Mhlongo, traditional healers received no assistance from the Department of Health nor medical equipment to fight the spread of the virus. Not even clean water, which is essential for the healing treatment provided by traditional healers, was provided to healers. Reflecting critically on the claims by Hlathi and Mhlongo, one needs to indicate that their claims are unsubstantiated. It is possible that traditional healers have and are still participating in fighting Covid-19 by using traditional medicine. This study has no means to confirm whether this has indeed happened, but it is indeed possible. What is however true of their claim is that traditional healers were not consulted officially nor appointed officially in the fight against Covid-19.

According to the interviews conducted with Dr S. Hlathi (Interview on SABC News https:/ / www.youtube.com/watc h?v=JhrpukCzfMI\&feature=share, accessed 28/03/2020) and Mr. S. Mhlongo (Interview on SABC News https:// www.youtube.com/watch?v=tdGCjYgf1F0\&feature=share, accessed 28/03/2020), traditional healers claim that they can assist in the fight against the spread of the virus, but they have not been asked by the Department of Health to do so. Traditional healers believe that they can assist in the fight against Covid-19 in various ways.

One traditional healer, Nombulelo Doreen Ndiko from Carltonville, commented in an interview with Phumlani Langa (2020) from City Press that traditional healers can explain the meaning of the outbreak of the virus by 'reading the bones'. The means of healing is explained by a traditional healer in East London, Zandile Ntombela, who stated that 'sangomas were traditional doctors led by ancestral spirits' (Palezweni 2020). Although the method of healing by traditional healers differs from health workers deployed by the Department of Health, the same goals and results can be achieved (Palezweni 2020). Traditional healers also complained that because of the regulations on social distancing and movement, healers are restricted and confined to their homes. This confinement prevents them from gathering the necessary herbs for treatment or the ability to consult with the spirits (Palezweni 2020).

It should be kept in mind that $80 \%-90 \%$ of black patients in South Africa consult traditional healers as well as biomedical health practitioners (Pinkoane, Greeff \& Koen 2012:13). According to De Andrade (2012:120), 70\% - 80\% of people living in South Africa consult traditional healers before consulting other healthcare practitioners (compare Setswe 1999:57). Mokgobi (2014:2) adds to this that $70 \%-80 \%$ of Africans consult traditional healers for physiological, psychiatric and spiritual needs. There is, therefore, clearly a huge demand for assistance from traditional healers.

This research aims to investigate the reasons why traditional healers are not incorporated in the fight against Covid-19 in South Africa. This is not an investigation as to the validity and efficiency of treatment provided by traditional healers, but an investigation as to why traditional healers, even though officially recognised as part of the healthcare system, are not permitted to participate officially in the treatment and prevention of Covid-19 in South Africa.

The research followed a methodology of relying on published literature as the source. To a large extent, the research is a literature study. To some extent, the research also employs a qualitative approach as it relies on anecdotal accounts and information derived from media interviews. Creswell (2015:3) indicates that in a qualitative approach, the researcher poses questions and collects data in the form of text, audio or video recordings. This is the case in this study. The data are analysed, and results are interpreted. The main limitation of information gained through qualitative means is that it tends to be highly subjective (Creswell 2015:5). A qualitative approach is also based on the views of participants and not necessarily those of the researcher. These are in fact the opinions of individuals expressing their views based on personal experiences. This approach contributes to the assumption that the research contains unsubstantiated generalisations. The researcher endeavoured to engage critically with the views expressed by individuals.

Before presenting an interpretation of the data, it is necessary to determine the official status and the recognition traditional healers enjoy in the South African healthcare system. Based on the literature consulted, several reasons why traditional healers are not incorporated in the fight against Covid-19 in South Africa will be presented. From this, several suggestions as to how to proceed from the impasse will be presented.

\section{Official status of traditional healers in the South African healthcare system}

Traditional healers in Africa are known by different names. In Xhosa, they are known as Igqirha, Ngaka in Northern Sotho, Selaoli in Southern Sotho, and Mungome in Venda and Tsonga. Most South Africans refer to traditional healers as Sangomas, deriving from the Zulu word Izangoma (Mokhoathi 2017:5).

It is important to emphasise that the activities of traditional healers are diverse. Truter (2007:57) indicates that the sangoma refers to the most senior of the traditional healers. The sangoma is the person who not only performs a diagnosis and defines the illness but also divines the circumstances of the illness within a cultural context. All Sangomas do not 
perform similar functions. They also do not fall into the same category. Traditional healers, each have a field of expertise in which they use their own methods of diagnosis and a particular set of knowledge skills in traditional healing and traditional medicines. The common denomination of 'diviner' needs to be defined. Divining is not only communicating with the spirits but also viewing the spiritual in the physical world of the inflicted and interpreting the related events (Henriques 2013:58). A herbalist, however, administers herbal remedies.

In order to regulate the activities of traditional health practitioners, several associations have been established in South Africa of which the following are the most prominent: 'Traditional Healers' Organization', the 'South African Traditional Healers' Council', the 'African National Healers' Association', the 'African Dingaka Association' and the 'Traditional Healers' and Herbalist Association' (De Andrade 2012:125).

The South African Department of Health recognised and institutionalised traditional medicine and healing practices by establishing a directorate of Traditional Medicine within the Department of Health (Moshabela, Zuma \& Gaede 2016:84). A statutory body regulating the approximately 200 000-300 000 traditional healers (compare Mothibe \& Sibanda 2019:13) in South Africa was established in 2007 under the Traditional Health Practitioners Act, no. 22 of 2007 (Mothibe \& Sibanda 2019:5; Street 2016:325). The act makes provision for four categories of traditional health practitioners: diviners (sangomas), herbalists (inyanga), traditional birth attendants (ababelethisi) and traditional surgeons (ingcibi) (Setswe 1999:57; Street 2016:325). Moshabela et al. (2016:85) indicate that faith healers are not included in the list of recognised categories in the act. These faith healers are typically prophets acting in African Christian Churches and performing acts of healing (Moshabela et al. 2016:85). The act provides legal recognition to the named traditional healers, although they are not included by the Department of Health in the list of health providers, as traditional medicine needs to be scientifically tested first (Pinkoane et al. 2012:12).

The act makes provision for a Council appointed by the Minister of Health and consists of representatives from the four named recognised categories along with provincial representatives and a representative from each of the Health Professions Council of South Africa and South African Pharmacy Council and members of the Department of Health (Street 2016:325). Since 2014 this council regulates registration, training and practice of traditional health practitioners in South Africa.

It is clear that traditional healers are recognised by the Department of Health as part of the healthcare system functioning in South Africa. They are recognised and respected members of the health community, officially incorporated in the workings of the government structure and providing a legitimate service to the people of the country. They are even legally obliged to provide sick certificates to patients
(Moshabela et al. 2016:87). Members of the Traditional Health Practitioners Council will be able to, through the Council, negotiate with medical aid schemes to pay for the services they provide to patients (Maravanyika 2008). By paying for the services of traditional health practitioners, medical aid schemes acknowledge the activities of traditional healers as part of the healthcare system. Even the World Health Organisation (WHO) (Jacobs 2020) recognises the benefits of traditional healing and the validity of the treatment. They, however, state that the remedies should go through the same testing process as modern medicine.

Traditional health practitioners have practised under these conditions in South Africa for over a decade now. During the outbreak of Human Immunodeficiency Virus-Acquired Immune Deficiency Syndrome (HIV-AIDS), the contribution of traditional healers once again came under the spotlight. A great deal of negative publicity regarding their treatment of HIV-AIDS contributed to the controversy of the validity of the treatment they provide (Moshabela et al. 2016:84). This contributed to an atmosphere of 'mistrust, tension and unresolved issues' and even 'conflict' between traditional and biomedical healers (Moshabela et al. 2016:84, 85). De Andrade (2012:121) confirms that this mistrust is because of misunderstandings and differences in worldviews. It is this mistrust and tension that now once again drives the conversation between the Department of Health and traditional healers in their plea to be included in the treatment of Covid-19.

Although there are attempts being made to prove the opposite, the healthcare provided by traditional healers is not seen as being on the same level as biomedical healthcare (Moshabela et al. 2016:85). It might be appropriate at this stage to explain the polarity or 'medical plurality' as Moshabela et al. (2016:85) referred to it.

Moshabela et al. (2016:84) differentiate between two paradigms, which determine medical treatment: the 'biomedical paradigm' based on scientific (science of biology) knowledge and the 'healing paradigm' based on indigenous and religious knowledge. Some other authors agree with this differentiation of worldviews (compare De Andrade 2012:121; Henriques 2013:60). These paradigms represent different worldviews. People subscribing to a particular worldview will consult with a healer who understands and functions within a particular worldview. Traditional healers provide the service for which there is a demand amongst people living within a particular worldview. Biomedicine claims to be neutral and realistic, whilst traditional healing is accused of being based on irrational knowledge deriving its healing properties from spiritual forces, especially through the spirits of the ancestors who are considered just below God the creator and Supreme Being (Moshabela et al. 2016:85, 86). Biomedicine relies on a biological cure after treatment, whilst traditional healing depends on a spiritual approach. Biomedicine applies expert-driven standard procedures of treatment, whilst traditional healing presents a personalised form of treatment requiring participation from the side of the 
patient (Moshabela et al. 2016:86). Biomedical treatment, similar to traditional healing, requires a proper diagnosis of the illness. Traditional healing emphasises on the origin of the disease more than the cure for the disease. Traditional healing can explain to patients the reason for the illness, which is mostly attributed to malevolent forces acting against the individual and not random infections as proposed by biomedical treatment. In traditional healing, jealousy of others is also considered as a cause for contracting illness (Moshabela et al. 2016:86). Traditional healing then not only becomes the treatment of a disease but also the treatment of the effect of witchcraft.

In light of the differences between biomedical and traditional healing, it is clear how tension, mistrust and even conflict can occur between representatives of the two systems. Proprietors of biomedical medicine can be suspicious of the treatment provided by traditional healers, as there is no proof and evidence of the effectiveness of the healing methods of traditional healers (Moshabela et al. 2016:85). Treatment provided by traditional healers through medicinal plants causes toxicity in the human body and delays treatment by biomedical means (Moshabela et al. 2016:84). Traditional healing is perceived not to be of the same standard as biomedical treatment. Biomedical treatment is perceived to be supreme in terms of a hierarchical classification of knowledge (Moshabela et al. 2016:85). Although traditional healers are recognised as part of the healthcare system in South Africa, the treatment they provide is not recognised legally, as it still requires scientific testing before it can be placed on equal footing with biomedical treatment.

These arguments contribute to the reasons why traditional healers are prohibited from participating in the treatment of the Covid-19 pandemic. It is, however, not only the lack of scientific testing preventing traditional healers from participation in treatment; there are other reasons too for their exclusion.

\section{Reasons for not allowing participation in fighting Covid-19}

Why are traditional healers not permitted to participate in the fight against Covid-19? Why are their calls to be included in the organised process by the Department of Health to fight Covid-19 ignored? What are the reasons for the mistrust, tension and even conflict between traditional healers and biomedical practitioners? This study suggests the following as contributing reasons why traditional healers are not included in the fight against Covid-19. Based on the literature represented in the previous section, the following reasons are identified: ideological, economical and biomedical reasons, and largely, professional jealousy.

\section{Ideological reasons}

The clash between traditional healers and biomedical healers is a clash of sciences. The Western-inspired form of science stands in opposition to the African style of science, which is influenced by indigenous knowledge systems. This clash is the manifestation of a clash of worldviews (Moshabela et al. 2016:84). This is, however, not only a unique African worldview opposing the Western-inspired worldview. Charles Taylor (2007) describes the different worldviews in terms of how humans perceive their existence, in reality, and in relation to their environment. For Taylor, humans have two ways of assigning meaning to reality: one way is to locate all meaning within the human mind. Another way is to allocate meaning to entities outside of the human mind. The result is that humans are open, Taylor (2007:38) refers to this position as being 'porous', to influence from the outside world. Forces residing outside of the human mind can enter the human world, cause disruption and create harmony. It is this 'porous self', which perceives illness and disease as caused by forces outside of humans. Healing is then to be sought in the same fashion: from the forces outside of humans. Causality drives existence: everything happening, disease and healing, is caused by something.

The opposite understanding of human existence, in reality, depicts a human as being closed (Taylor 2007:37 refers to the 'buffered self') to influence from outside the human mind. Humans are self-reliant and participate in bringing about results in the world. No exterior force affects human behaviour. Illness has an explanation created in the human mind. Healing comes through human participation in creating and administering a cure. The 'buffered self' has been associated with a Western mindset, whilst the 'porous self' is prevalent amongst many cultures all over the world and not only in Africa.

The difference in worldviews causes a clash. The 'buffered self' as presented and spread across the world through colonialisation came into contact with the 'porous self'. Existing as a 'porous self' was and in some cases, still is, depicted as a barbaric and primitive way of existing (compare Moshabela et al. 2016:86). Historically, traditional healers are perceived to continue with this barbaric and primitive way of existence (De Andrade 2012:122). During the colonial and apartheid era in the history of South Africa, traditional healers were not recognised as medical practitioners and denigrated to the level of herbalists and witchdoctors by the Witchcraft Suppression Act no. 3 of 1957 (Moshabela et al. 2016:87). By imposing biased laws, the 'buffered self' exerted power over the traditional way of healing.

The stigmatisation of traditional healing has not been eradicated. Even though new laws and measures have been put in place (compare the discussion of government attempts at recognising traditional healers within the Traditional Healers Act no. 22 of 2007), the process has not come full circle. Stigmas and biases have not been removed. Traditional healers may be recognised as part of the healthcare system, but their treatments are not recognised, as these still need to be tested scientifically before they are considered on the same level as biomedical treatments. Even though the treatments of traditional healers are mainly directed at 
emotional, psychological and social distress, they are still measured by the same criteria as biomedical treatment, which is directed at treating the biological system. Perhaps, biomedical practitioners do not understand (De Andrade 2012:121) the calling and functioning of traditional healers, and this causes tension, misunderstanding and conflict.

With a differentiation in foci, traditional healers focussing on the social-psychological healing and biomedical treatment focussing on the physiological healing, there might be space for both types of healers to coexist (compare Setswe 1999:57). In this way, traditional healers can operate alongside biomedical practitioners, both not infringing on the terrain of the other. This will, however, require mutual agreement and respect for the validity of treatment presented by both.

\section{Economic reasons}

The South African Pharmaceutical Industry Report (2019) indicates that the pharmaceutical industry is responsible for research, development, marketing and distribution of drugs. The industry in South Africa reached a value in 2019 of R68 billion in terms of retail sales. The report further indicates that the biggest challenges for the industry are the growing accessibility to and affordability of drugs, as well as the growing South African manufacturing capacity to produce drugs. This is a highly successful financial industry with good prospects of growth.

In light of the potential benefit to the industry, the question might be asked why not test, develop and market remedies based on traditional medicine and help traditional healers to share in the proceeds and processes. Pott and Wink (2016) indicate that 'the pharmaceutical industry is not generally that interested in medicinal plants as they do not contain a single definable and completely new active ingredient'. It seems as if the industry does not need traditional healers in terms of developing and marketing drugs with better healing properties. The industry might also be reluctant to share profit on the sales of drugs with the traditional healers. The whole debate on intellectual property on indigenous knowledge illustrates this point (Mothibe \& Sibanda 2019:10).

It is important to note that the WHO reports that there is a steady increase worldwide in the use of traditional medicine (Mothibe \& Sibanda 2019:1). In South Africa, however, the plea for recognition and incorporation of traditional healers and traditional medicine into the healthcare system seems to have encountered some challenges. Louw and Duvenhage (2017a:250) indicate that the development of traditional medicine in South Africa has been stunted, blocked and ignored by the official healthcare sector. The reason for ignoring traditional medicine is attributed to pharmaceutical companies: '... the lobbying of pharmaceutical cartels after 1994, together with the hostile attitude of medical doctors and medical regulators, are destroying the South African traditional healers' unique traditional medicine' (Louw \& Duvenhage 2017a:250).
Owing to financial considerations, traditional healers are not permitted to treat or administer treatment in the fight against Covid-19, as the pharmaceutical industry stands to lose income when treatment is not channelled through recognised medicine. Regulatory institutions stand the change to lose control over the monopoly of drug distribution once traditional medicine is acknowledged.

\section{Biomedical}

The bona fide objection by the Department of Health against traditional healers participating in the fight against Covid-19 should be noted. The Department of Health may be aware of the risk of traditional healers contracting the Covid-19 infection whilst coming in contact with infected patients. In order to limit the contact with patients, the department is preventing traditional healers from treating patients with Covid-19. Only staff members who are trained and provided with necessary medical equipment, such as masks and appropriate protective clothing, are permitted to participate in the official strategy of the Department of Health to combat Covid-19.

The Department of Health has no control or power of prescription over traditional healers. This results in lack of uniformity in the treatment provided by traditional healer and lack of monitoring of the progress as a result of the treatment (Pinkoane et al. 2012:12). This only contributes to the frustration of the Department of Health, as they have no indication and reassurance that potential patients have been tested for Covid-19 infection, isolated and treated appropriately, if necessary. The experience of biomedical practitioners is that patients, after consulting with traditional healers, receive ineffective treatment and finally consult biomedical practitioners for biomedical treatment (De Andrade 2012:120; compare Pinkoane et al. 2012:12).

The claim by traditional healers to have healing powers by administering traditional medicine is presented as being a myth (Louw \& Duvenhage 2017a:251). Healing powers reside in the plants and with the guidance of ancestral spirits, the cause of the disease can be identified (De Andrade 2012:122). Traditional medicine can be smoked, inhaled, drunk, used for washing or applied as an ointment on the body (De Andrade 2012:122). Most of the traditional medicine has not been researched scientifically, and it is still an ongoing process (compare Mothibe \& Sibanda 2019:7). Giving only marginal recognition to traditional healers in official government legislation is merely an act of political correctness to prevent any challenges from being thrown by traditional healers (Louw \& Duvenhage 2017a:251). It is, however, a pity that there is no differentiation made between what is referred to as muti and real traditional medicine. The first would refer to concoctions of some sort, and the second would refer to utilising recognised healing properties of medicinal plants. Owing to concerns by biomedical health practitioners as to the healing effect of traditional medicine, traditional healers are prevented from administering remedies during the Covid-19 pandemic. 
The effect and healing properties of traditional medicine are a highly complex matter and have been researched and published extensively (De Andrade 2012; compare Mothibe \& Sibanda 2019). It is not the purpose of this study to determine the validity or efficiency of traditional medicine, but rather to investigate ways in which traditional healers can participate in the fight against Covid-19.

\section{Professional jealousy}

The tension, mistrust and conflict between traditional healers and biomedical practitioners have existed for some time. Much of it is because of stereotyping already started by the missionaries coming to Africa during the colonial period, depicting traditional healers as primitive and practitioners of witchcraft (Moshabela et al. 2016:87). The effects of the remedies provided by traditional healers are also controversial (De Andrade 2012:120), as these medications have not been tested in a controlled environment. Biomedical practitioners historically worked hand in hand with missionaries to convert people to Christianity (Moshabela et al. 2016:85), creating suspicion regarding the intentions of biomedical practitioners. The level of training may cause biomedical practitioners to experience a feeling of superiority (De Andrade 2012:121) when compared to the training of traditional healers.

Traditional healers prepare medicine for treatment, mostly from plant material and present it untested as a remedy (De Andrade 2012:122). No record of storage, side effects or dosage is kept. Treatment is paid for by patients, and the revenue is substantial (Moshabela et al. 2016:87). Ingredients used in treatment can be toxic (Mothibe \& Sibanda 2019:9). Treatment is not necessarily based on the healing properties of plants but mostly relies on directives by ancestors on what treatment to provide (Moshabela et al. 2016:87). Traditional medicine does not meet the standards of biomedical treatment and confirms the supremacy of biomedical treatment.

It appears as if traditional healers were never taken seriously. Louw and Duvenhage (2017b:73) indicate that traditional healers were never afforded a clear medical identity in South Africa. The reason is that there never has been trust in their healing methods as it relies on religious knowledge. They can at most, be identified as priest healers (Louw \& Duvenhage 2017b:74).

Over centuries of practice, the biomedical practitioners have become the guardians and experts in dispersing healthcare (Mothibe \& Sibanda 2019:9). Louw and Duvenhage (2017c:95) indicate that medical doctors are still in charge of healthcare management. 'This fraternity serves as gatekeepers', determining who will be allowed into the profession (Louw \& Duvenhage 2017c:95). The medical doctors' interest is well established, and they are unwilling to relinquish this power (Louw \& Duvenhage 2017c:96). The privileges that accompany the position of power are jealously guarded.
About $70 \%-80 \%$ of Africans consider traditional healers as their first point of contact in times of illness and disease. Traditional healers do not impose their treatment on people. Nor is it the affordability of the treatment they provide that convinces people to consult with them. The supply of traditional treatment caters to the needs of an existing market. Traditional healers operating within a particular worldview treat people subscribing to the same worldview. People are familiar with the treatment because it has been culturally transferred from one generation to the next for centuries (De Andrade 2012:122). For those consulting the traditional healer, there is no reason to doubt the curing properties of the treatment provided.

This obstinate and blind belief in the powers of the seemingly irrational and untested treatment by traditional healers creates a professional jealousy amongst biomedical practitioners.

\section{Recommendations for a way forward}

The controversy over the treatment provided by traditional healers will still continue long after the last effects of the Covid-19 pandemic are over. Perhaps, the plea of traditional healers to be included in the strategy of the Department of Health treatment plan for Covid-19 provides opportunities to reconfigure the relations between biomedical and traditional health practitioners.

\section{Opportunity for collaboration}

Despite mistrust and jealousy, there is a need for collaboration between traditional healers and biomedical health practitioners (Mothibe \& Sibanda 2019:9). There is a different way in which biomedical practitioners can view traditional healers. Mokgobi (2014:5) argues that Western-trained medical practitioners are ignorant of the cultural construction of illness and disease and do not know how traditional healing works. Knowledge of traditional healing should be encouraged amongst Western-trained medical practitioners (Mokgobi 2014:9). It is the cultural construction of illness that requires a different treatment from what Western medicine provides. The cultural construction of illness and treatment makes people from Africa sceptic about the Western treatment of the disease, especially psychiatric conditions, for example, schizophrenia (Mokgobi 2014:3). These medical conditions are according to an African understanding caused by witchcraft and therefore, require a different form of treatment Western medicine can provide.

Mokgobi (2014:7), in an investigation where Westerntrained medical practitioners were interviewed, came to the conclusion that $66 \%$ of the medical practitioners interviewed indicated that they seldom or never have seen patients who were effectively treated by traditional healers. Medical practitioners interviewed by Mokgobi (2014:9) indicated that there are some illnesses and diseases that traditional 
healers can treat. This includes diseases such as sexually transmitted infections, constipation, diarrhoea and rashes. Some psychiatric conditions believed to be the result of witchcraft can also be treated by traditional healers.

Some scholars (compare Pinkoane et al. 2012:16-17) attempted to construct a plan on how to incorporate traditional healers in the national healthcare system. Their plan includes creating a controlled environment where traditional healers are advised and mentored, and can be utilised in administering medicine. Mothibe and Sibanda (2019:6) identify efforts made to incorporate traditional medicine in the national healthcare system. These efforts of collaboration need to be continued and expanded. A first step would be to create an awareness amongst biomedical practitioners of the different ways in which the origin of illness and healing is culturally constructed. This awareness can lead to the exchange of knowledge.

\section{Opportunity to exchange knowledge}

One of the main reasons for mistrust and even conflict between biomedical and traditional health practitioners is that they learn different things (De Andrade 2012:121). By reciprocal exchange of knowledge (Pinkoane et al. 2012:13), exposure to the knowledge of the other can be created. This may be increased if there is a process of reciprocal referrals (Pinkoane et al. 2012:17).

In South Africa, there is a need for more healthcare practitioners. In order to increase the amount of hands, the available manpower of the traditional healers can be utilised in a controlled environment to meet the medical needs of people (Setswe 1999:58).

Street (2016:326) suggests that part of the solution may be to regulate the training of traditional healers by registering training at Training Institutions according to the regulations governing education and training. No institution in South Africa is currently providing any training in administering traditional medicine (Mothibe \& Sibanda 2019:11), and this needs to be addressed.

Knowledge of medicinal properties of plants increases as more research is conducted. Mothibe and Sibanda (2019:9) indicate that although research at many levels is taking place, these efforts are uncoordinated, contributing to the delay of implementing traditional medicine in the National HealthCare system. By increasing the knowledge of traditional medicine, stigmas might disappear.

\section{Opportunity to correct misconceptions}

With the necessary knowledge conveyed, a misconception can be corrected. Through increased knowledge and better understanding, myths about traditional medicine can be dispelled (De Andrade 2012:126). A contributing factor causing mistrust amongst health practitioners and traditional healers is the difference in worldview. This is emphasised by several scholars (De Andrade 2012:121, Moshabela et al. 2016:85; Setswe 1999:57). To address mistrust and tension does not require a change in worldview, but merely becoming aware of the differences in existing worldviews and respecting the differences.

With the understanding of worldviews, an explanation as to the role traditional medicine plays becomes clear. Different worldviews require different treatments, and hence, the plurality of biomedical and traditional medical practices. Society will continue to be in need of traditional healers and will continue to consult with them as the culture and worldviews of communities did not change with the introduction of biomedical treatment (Setswe 1999:58). Besides, traditional healers are more accessible to rural communities as compared to biomedical health practitioners. This echoes the call by Hlathi that traditional healers should be permitted to participate in the fight against Covid-19, especially in distant rural areas.

Street (2106:326) indicates that although the Traditional Health Practitioners Act no. 22 of 2007 provides legal acknowledgement of traditional healers, the act does not provide for the regulation of traditional medicine. What is outstanding is to bring the traditional medicine products under the existing regulations regulating the prescription of medicine in the South African healthcare system. This will place traditional medicine on the same level as biomedical remedies that are also subjected to the same stringent tests.

\section{Opportunity to differentiate treatment}

Pinkoane et al. (2012:13) suggest that differentiation at all levels will prevent mistrust. If traditional healers are allowed to operate autonomously and self-regulate, they will not be a threat to biomedical health practitioners.

Traditional healers heal, but on a different level than biomedical health practitioners. Where biomedical treatment is focussed at the psychosomatic treatment, traditional medicine is directed at psycho-socio-economic treatment (Moshabela et al. 2016:85; Setswe 1999:57). Traditional healing sees an individual as a whole, not as a being separated between body and mind, and also as a member of society, family or community. The whole human being is treated comprehensively; the needs of the whole being within a wider social context are addressed. Healing can be differentiated between what traditional healers can do and what biomedical health practitioners can do.

Traditional healers can perform some healing tasks that are recognised by biomedical practitioners. Setswe (1999:58-59) indicates that preventative tasks can be performed by traditional healers. They can provide communities with education and warnings on personal hygiene, indicating the importance of diet, exercise and performing of rituals. They can be utilised as psychosocial healers to address the stress and despair people might be experiencing during the Covid-19 pandemic.

There appears to be space for both traditional and biomedical health practitioners to coexist and practise alongside one 
another. As De Andrade (2012:122) emphasises, both seem to treat different ailments: biomedical treatment is for physical and psychological disease. Traditional healing heals the societal effects of inflicted harm caused by harmful forces on society. Perhaps, both traditional and biomedical health practitioners are necessary for treating the ill. There appears to be room for both groups to participate in the fight against Covid-19.

Until traditional healers are perceived as acting on the same level as biomedical health practitioners, traditional healers will fall victim to their own understanding of the working of the universe and to their method of healing. Illness, disease and crisis have a cause. Diagnosing and treating the correct and true spiritual cause will result in healing. Causality thus governs the healing process. The true cause of illness, according to an African worldview, is the malicious wishes of others manifested in the disease cast on one through the workings of mediums of witchcraft.

The fact that traditional healers are not allowed to participate in the fight against Covid-19 can be perceived as a result of malevolent forces acting against them; in this case not forces of spiritual origin, but of a biophysical nature in the opposition embodied in the representatives of the biomedical healing profession. The conversation on the participation of traditional healers in the treatment of Covid-19 does not resolve any problems, but it does create opportunities to address matters underlying the tension and mistrust between traditional and biomedical health practitioners. The conversation on the underlying causes is the conversation that needs to be continued, especially after Covid-19.

\section{Acknowledgements Competing interests}

The author has declared that no competing interest exists.

\section{Author's contributions}

I declare that I am the sole author of this research article.

\section{Ethical considerations}

This article followed all ethical standards for a research without direct contact with human or animal subjects.

\section{Funding information}

This research received no specific grant from any funding agency in the public, commercial or not-for-profit sectors.

\section{Data availability statement}

Data sharing is not applicable to this article as no new data were created or analysed during this study.

\section{Disclaimer}

The views and opinions expressed in this article are those of the authors and do not necessarily reflect the official policy or position of any affiliated agency of the author.

\section{References}

Creswell, J.W., 2015, A concise introduction to mixed methods research, Sage, Thousand Oaks, CA.

De Andrade, V., 2012, "'Traditional healers and modern doctors do not understand each other because they learn different things" South African traditional health practitioners' training with regards to hearing impairment', International Journal of Health Promotion and Education 49(3), 120-127. https://doi.org/10.1080/146 35240.2011.10708218

Henriques, H.C., 2013, 'Environment, worldviews and healing among Zulu Christians (19th and 20th centuries)', Studia Historiae Ecclesiasticae 39(2), 57-69.

Jacobs, K., 2020, 'WHO recognises traditional medicine in treating Covid-19', Cape \{town\}etc, viewed 07 May 2020, from https://www.capetownetc.com/news/whorecognises-traditional-medicine-in-covid-19-treatment/.

Langa, P.S., 2020, 'We spoke to a traditional healer about Covid-19', City Press, 27 March, viewed 28 April 2020, from www.city-press.news24.com.

Louw, G. \& Duvenhage, A., 2017a, 'True ownership of traditional medicine in South Africa', Australasian Medical Journal 10(4), 249-256. https://doi.org/10.21767/ amj.2016.2734

Louw, G. \& Duvenhage, A., 2017b, 'Does the traditional healer have a modern medical identity in South Africa?', Australasian Medical Journal 10(2), 72-77. https://doi. org/10.21767/amj.2017.2730

Louw, G. \& Duvenhage, A., 2017c, 'Will the traditional health care practitioners act (Act no 22 of 2007) challenge the holy grail of South African doctors?', Australasian Medical Journal 10(2), 95-102.

Maravanyika, B., 2008, 'Traditional healers to claim medical aid', IOL, 19 January, viewed 05 May 2020, from https://www.iol.co.za/news/south-africa/traditionalhealers-to-claim-medical-aids-386291.

Mokgobi, M.G., 2014, 'Western-trained health care practitioners' knowledge of and experiences with traditional healing', African Journal of Physical, Health Education, Recreation and Dance 2014(suppl. 2), 1-13.

Mokhoathi, J., 2017, 'From contextual theology to African Christianity: The consideration of adiaphora from a South African perspective', Religions 8(266), 1-14. https://doi.org/10.3390/rel8120266

Moshabela, M., Zuma, T. \& Gaede, B., 2016, 'Bridging the gap between biomedical and traditional health practitioners in South Africa', South African Health Review $8,83-92$.

Mothibe, M.E. \& Sibanda, M., 2019, 'African traditional medicine: South African perspective', in Traditional and Complimentary Medicine, InTechOpen, viewed 18 May 2020, from https://doi.org/10.5772/intechopen.83790

Palezweni, Y., 2020, 'Traditional healers not sure if they are essential service', DispatchLive, 18 April, viewed 28 April 2020, from https://www.dispatchlive. co.za.

Pinkoane, M.G., Greeff, M. \& Koen, M.P., 2012, 'A model for the incorporation of traditional healers into the national health care delivery system of South Africa', African Journal of Traditional Complement Alternative Medicine 9(3S), 12-18. https://doi.org/10.1111/j.2042-7166.2006.tb04775.x

Pott, A. \& Wink, M., 2016, The great untapped potential of herbal medicines, Healthcare Industry BW, viewed 18 May 2020, from https://www.gesundheit sindustrie-bw.de/en/article/news/the-great-untapped-potential-of-herbalmedicines.

Setswe, G., 1999, 'The role of traditional healers and primary health care in South Africa', Health SA Gesondheid 4(2), 56-60. https://doi.org/10.4102/hsag. v4i2.356

South African Pharmaceutical Industry Report, 2019, viewed 18 May 2020, from https://www.prnewswire.com/news-releases/south-africa-pharmaceuticalindustry-report-2019-300863387.html.

Street, R.A., 2016, 'Unpacking the new proposed regulations for South African traditional health practitioners', South African Medical Journal 106(4), 325-326. https://doi.org/10.7196/SAMJ.2016.v106i4.10623

Taylor, C., 2007, A secular age, The Belknap Press of Harvard University Press, Cambridge, MA.

Truter, I., 2007, 'African traditional healers: Cultural and religious beliefs intertwined in a holistic way', SA Pharmaceutical Journal 74(1), 56-60. 